\title{
Study of Ship Main Engine Dynamic Fuel Consumption Model
}

\author{
Dianhu Du \\ China Waterborne Transportation Research Institute, Beijing 100088, China \\ E-mail: orangez80@163.com
}

\begin{abstract}
In this paper, a type of understudied Inland Shallow and wide ship is studied. Combined with the real ship design parameters and ship model test data, the ship dynamic fuel consumption model is established. The ship's speed and fuel consumption are quantitatively calculated and predicted, provides basic data for determining ship economic speed.
\end{abstract}

Keywords: Ship, Dynamic Fuel, Consumption, Output Power, Model.

\section{Introduction}

At present, the unit consumption of inland navigation energy in China is about 50\% higher than that of foreign countries and the advanced energy conservation and emission reduction technology at home and abroad is not applied widely. As major industry of energy consumption, shipping enterprises desperately need to realize energy conservation and emission reduction by certain technologies and management means. So, we need to increase investment in manpower and material resources, start from technology, management and personnel, research on related technologies of shipping energy saving, improve energy saving and environmental protection level of ships and promote the construction and development of green shipping in China.

At the present stage, the most direct, convenient and effective way for energy conservation and emission reduction of inland ships is to navigate by adopting economic speed. The relationship of ship navigational speed and fuel consumption, inland water velocity, freight period and other factors shall be considered comprehensively for the determination of economic speed of inland ship. The relationship of ship navigational speed and fuel consumption is the basis for determining economic speed.

\section{Study of Ship Mathematic Relationships}

Taking related information in professional skill fields such as shipping principle, ship design, main engine model selection and mathematical modeling as references, this paper selects critical limiting factors related with ship fuel consumption. Taking a 6700 tons broad-shallow bulk carrier as modeling project and taking ship design data, related data of ship main engine as modeling basis, a quantitative ship main engine dynamic fuel control model is built by applying mathematical modeling method and instrument. This model indicates there is quantitative relation between ship speed and fuel consumption.

\section{Propeller efficiency}

Based on ship principle, the propeller efficiency is:

$$
\eta_{p}=\frac{K_{T}}{K_{Q}} \mathrm{~g} \frac{J}{2 \pi}
$$

Where:

$$
\begin{aligned}
& K_{T} \_ \text {thrust coefficient } \\
& K_{Q} \_ \text {torque coefficient } \\
& J \_ \text {advance coefficient }
\end{aligned}
$$




\section{Movement condition}

Advance coefficients $\mathrm{J}$ of propeller, its diameter $\mathrm{D}$, ship speed Vs and wake factor $\omega^{\mathrm{h}}$ have the following relationship:

$$
J-\frac{(1-\omega)}{n_{p} D} \mathrm{~g} V_{S}=0
$$

Where:

$$
\begin{aligned}
& D \_ \text {diameter of propeller, }(\mathrm{m}) ; \\
& n_{p} \_ \text {revolving speed of propeller; } \\
& \omega_{-} \text {wake factor; } \\
& V_{S} \_ \text {speed }(\mathrm{km} / \mathrm{h}) .
\end{aligned}
$$

\section{Force balance condition}

The effective thrust Te of propeller must be equal to the hull resistance $\mathrm{R}$ at a corresponding speed Vs, which is:

$$
\begin{gathered}
T_{e}-R=0 \\
T_{e}=(1-t) K_{T} \operatorname{gog} \eta_{p}^{2} D^{4} \\
R=\frac{1}{2} C \operatorname{gog} S V_{s}^{2}
\end{gathered}
$$

Where:

$$
\begin{aligned}
& \rho \_ \text {water density }(\mathrm{kg} / \mathrm{m} 3) ; \\
& t_{\perp} \text { thrust deduction coefficient; } \\
& C \_ \text {hull resistance coefficient; } \\
& S_{\perp} \text { hull area of water surface }(\mathrm{m} 3) .
\end{aligned}
$$

After transformation:

$$
K_{T}-\frac{R}{(1-t) \operatorname{g} \rho \mathrm{g}(1-\omega)^{2} V_{s}^{2}} \mathrm{~g} \frac{J^{2}}{D^{2}}=0
$$

\section{Energy conservation condition}

The power absorbed by propeller $\mathrm{Np}$ is equal to the power consumed by propeller, which is:

$$
N_{p}-2 \pi K_{Q} \operatorname{ggg} n_{p}^{3} \mathrm{~g} D^{5}=0
$$

After transformation:

$$
K_{Q}-\frac{N_{p}}{2 \pi \rho \operatorname{gn}_{p}^{3} D^{5}}=0
$$

\section{Ship fuel consumption}

When the ship is sailing at a certain speedVs, the unit time fuel consumption is:

$$
b_{e}=N_{e} \mathrm{gg}_{e}=\left[\frac{E H P\left(V_{s}\right)}{\eta_{e} \eta_{r} \eta_{h} \eta_{p}}\right] \mathrm{gg}_{e}
$$

Where:

$b_{e}$ unit time fuel consumption of main engine $(\mathrm{kg} / \mathrm{h})$

$N_{e} \_$output power of main engine $(\mathrm{kW})$

$g_{e} \_$fuel consumption rate of main engine $(\mathrm{kg} / \mathrm{km} . \mathrm{h})$ 
$E H P\left(V_{s}\right) \_$effective thrust power $(\mathrm{kW})$;

$\eta_{e} \_$_ shaft transmission efficiency;

$\eta_{r} \_$relative rotative efficiency;

$\eta_{h} \_$hull efficiency;

$\eta_{p} \_$rotative efficiency of propeller

The following relationship is deduced from the above formulas:

$$
\begin{gathered}
E H P\left(V_{s}\right)=T_{e} \mathrm{~g} V_{s}=(1-t) K_{T} \mathrm{~g} \rho \mathrm{g} \eta_{p}^{2} D^{4} \mathrm{~g} V_{s} \\
\operatorname{EHP}\left(V_{s}\right)=N_{e}=2 \pi K_{Q} \mathrm{~g} \rho \mathrm{g} \eta_{p}^{3} \mathrm{~g} D^{5}
\end{gathered}
$$

Because

$$
n_{p}=\frac{(1-\omega) V_{s}}{J D}
$$

Put it into the above two formulas:

$$
E H P\left(V_{s}\right)=(1-t) K_{T} \operatorname{g} \rho\left(\frac{1-\omega}{J}\right)^{2} \mathrm{~g} D^{2} \mathrm{~g} V_{s}^{3}=2 \pi K_{Q} \mathrm{~g} \rho\left(\frac{1-\omega}{J}\right)^{3} \mathrm{~g} D^{2} \mathrm{~g} V_{s}^{3}
$$

\section{Study of Propeller Characteristics}

The curve of propeller characteristics of diesel selected in this ship research project is as shown in Figure 1:

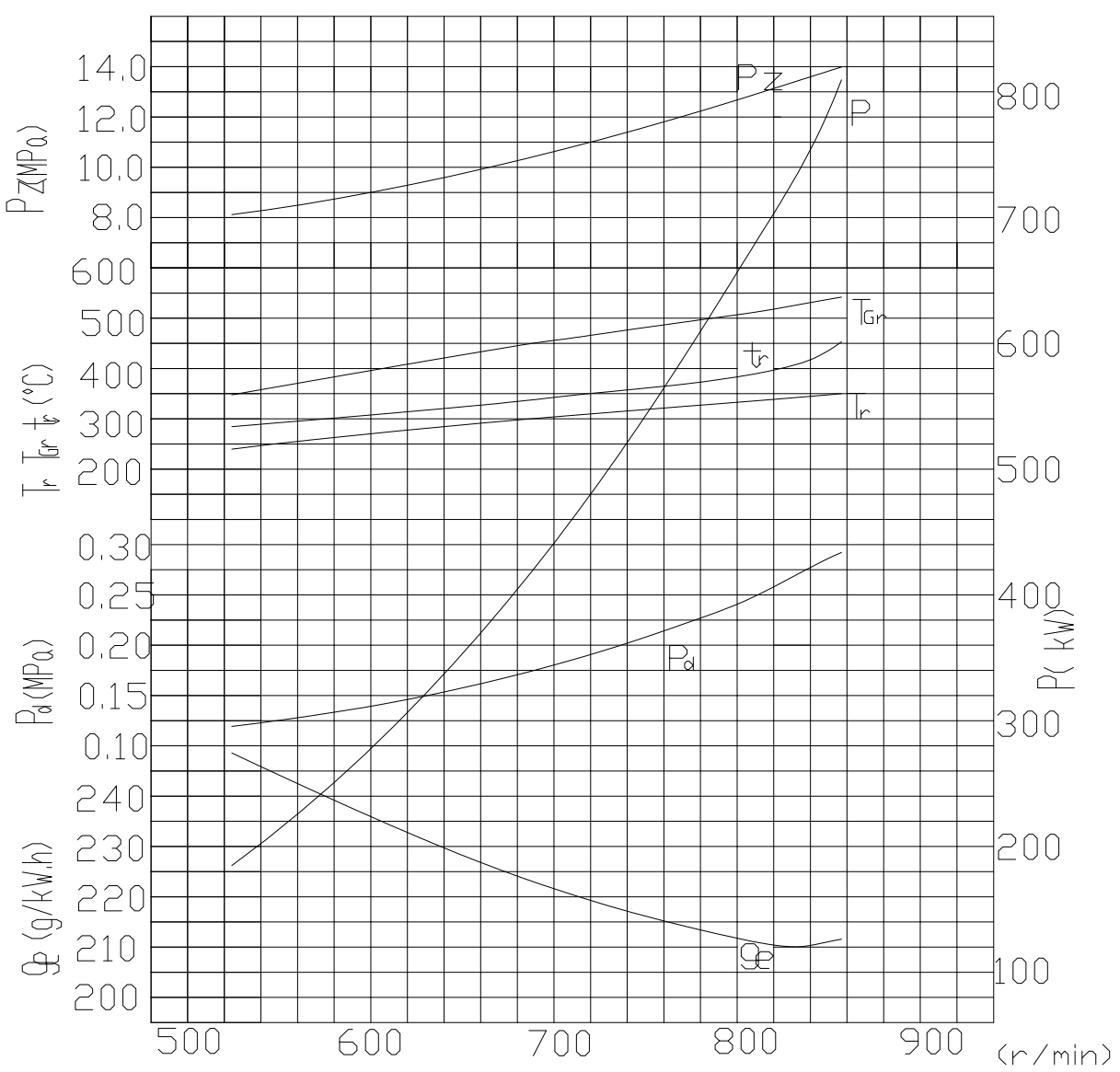

Figure 1 Curve of propeller characteristics of diesel 
Select a group of corresponding fuel consumption of main engine ge $(\mathrm{kg} / \mathrm{kw} \cdot \mathrm{h})$ and output power of main engine $\mathrm{P}(\mathrm{kW})$ at different rotate speeds from the curve, their relationship is as follows:

Table 1 Main Engine Relationships of Fuel Consumption and Output Power

\begin{tabular}{|c|c|c|c|c|c|c|c|c|c|}
\hline $\begin{array}{c}\text { Power of main } \\
\text { engine (kw) }\end{array}$ & 184 & 203 & 225 & 279 & 308 & 368 & 405 & 440 & 480 \\
\hline $\begin{array}{c}\text { Fuel consumption } \\
\text { rate (kg/kw.h) }\end{array}$ & 248 & 246 & 242.5 & 236 & 233 & 227 & 224 & 222 & 219 \\
\hline $\begin{array}{c}\text { Power of main } \\
\text { engine (kw) }\end{array}$ & 520 & 567 & 610 & 658 & 704 & 716 & 735 & 753 & 808 \\
\hline $\begin{array}{c}\text { Fuel consumption } \\
\text { rate (kg/kw.h) }\end{array}$ & 217.5 & 215 & 213 & 212 & 210.8 & 210.3 & 210 & 210.8 & 212 \\
\hline
\end{tabular}

Based on the above data, the relationship between the fuel consumption rate of main engine and output power of main engine is as follow:

$$
g_{e}=0.291-3.291 e^{-4} N_{e}+6.427 e^{-7} N_{e}^{2}-7.373 e^{-10} N_{e}^{3}+3.65 e^{-13} N_{e}^{4}
$$

So the fuel consumption in unit time when the ship is sailing at Vs is:

$$
b_{e}=N_{e} \mathrm{gg}_{e}=0.291 N_{e}-3.291 e^{-4} N_{e}^{2}+6.427 e^{-7} N_{e}^{3}-7.373 e^{-10} N_{e}^{4}+3.65 e^{-13} N_{e}^{5}
$$

Where

$$
N_{e}=\left[\frac{E H P\left(V_{s}\right)}{\eta_{e} \eta_{r} \eta_{h} \eta_{p}}\right]=\frac{2 \pi K_{Q} \mathrm{~g} \rho \oint\left(\frac{1-\omega}{J}\right)^{3} \mathrm{~g} D^{2} \mathrm{~g} V_{s}^{3}}{\eta_{e} \eta_{r} \eta_{h} \eta_{p}}
$$

\section{Conclusions}

The research and establishment of dynamic fuel consumption model of ship main engine provide the most basic data for inland ship to sail at economic speed and work out trip planning. By the calculation and prediction of model, we can get the fuel consumption data at different ship speeds. Under the condition that the freight period and voyage of ship are known, we can divide the ship voyage into several parts, with water velocity of specific voyage part and ship fuel consumption, we can plan the ship speed in order to let the ship sail at economic speed in the whole voyage and realize energy conservation and emission reduction of the ship.

\section{References}

[1] Q Cai, DJL Brett, D Browning, NP Brandon. A sizing-design methodology for hybrid fuel cell power systems and its application to an unmanned underwater vehicle[J]. Journal of Power Sources, 2010,195 (19):6559-6569

[2] Ren Wenjiang, Shi Runhua, Energy Conservation of Marine Power Plant [M]. Profile of Shanghai Jiao Tong University Press, 1991, 97-140.

[3] JJ Hwang. Thermal control and performance assessment of a proton exchanger membrane fuel cell generator[J]. Applied Energy, 2013, 108 (8) :184-193

[4] I Tolj, MV Lototskyy, MW Davids. Fuel cell-battery hybrid powered light electric vehicle (golf cart): Influence of fuel cell on the driving performance[J]. International Journal of Hydrogen Energy, 2013, 38 (25) :10630-10639 